\title{
ALITALIA AIRLINE: A BUSINESS CASE OF BAD CORPORATE GOVERNANCE
}

\author{
Maurizio La Rocca *, Francesco Fasano **, Gian Marco Napoli * \\ * University of Calabria, Italy \\ ** Corresponding author, Department of Business Administration and Law, University of Calabria, Italy \\ Contact details: Department of Business Administration and Law, University of Calabria, Campus of Arcavacata, 87036 Rende (CS), Italy
}

OPEN $\odot$ ACCESS

How to cite this paper: La Rocca, M. Fasano, F., \& Napoli, G. M. (2019). Alitalia airline: $A$ business case of bad corporate governance [Special issue]. Corporate Ownership \& Control, 17(1), pp. 264-277. http://doi.org/10.22495/cocvl7ilsiart9

Copyright $@ 2019$ The Authors

This work is licensed under a Creative Commons Attribution 4.0 International License (CC BY 4.0).

https://creativecommons.org/licenses /by/4.0/

ISSN Online: 1810-3057

ISSN Print: 1727-9232

Received: 02.10.2019

Accepted: 21.12.2019

JEL Classification: G34, 016 DOI: $10.22495 /$ cocvl7ilsiart9

\begin{abstract}
Corporate governance, allocating rights and responsibilities inside the firm, provides worthwhile guidelines that lead management to valuable processes and activities, which are the core of business success for the interests of all stakeholders. This paper provides evidence of an interesting business case in which many corporate governance rules were disregarded. In Alitalia airline company, the management, ignoring corporate governance aspects, strongly disrupted economic value. The study is based on the analysis of managerial profiles of Presidents and CEOs of Alitalia, evidencing their relationship with corporate governance issues. Moreover, we deeply investigated the story of Alitalia and the governments' political influence on the airline company. We found the absence of a proper mix of authority and responsibility, conflicts of interests and agency costs, poor monitoring activities, lack of managerial skills and scarce managerial effort, jointly with ineffective incentive mechanisms. The consequence was that past bad governance has compromised the ability of the company to create new value. We conclude that when governance principles are disregarded for a long time, even a high performing and cash-rich company can lose its competitive advantage, damaging its chances of a turnaround.
\end{abstract}

Keywords: Corporate Governance, Economic Value, Mismanagement, Bad Governance, Opportunism

Authors' individual contribution: Conceptualization -M.L.R.; Resources - F.F. and G.M.N.; Writing - Original Draft - F.F. and G.M.N.; Visualization - F.F. and G.M.N.; Supervision and Project Administration -M.L.R.

\section{INTRODUCTION}

The aim of this work is to study the noteworthy business case of the Italian airline company, Alitalia reporting many of the most relevant corporate governance aspects regarding value creation (components, dimensions, and determinants) described in the main managerial literature, as evidenced by La Rocca (2016). In particular, we specify how the components and dimensions of economic value affected its ability to create new value in turn. The framework of the paper is the analysis of a case study. We consider Alitalia airline an ideal company that perfectly suits for this kind of analysis, as many corporate governance issues emerged during the firm life-cycle. This case study is particularly significant as it practically confirms the corporate governance rules theorized by prior managerial studies. Several circumstances throughout the Italian airline's life explain the effects of bad governance, the consequences of which still are evident. Alitalia is a striking case suggesting how a competitive advantage of a firm can be destroyed due to bad governance, which leads a profitable company to financial constrain. With this work, we intend to provide a practical case of corporate governance, trying to combine practice and theoretical hot topics aspects. The purpose of the investigation is thus to highlight a remarkable case study to appreciate how mismanagement, focusing on non-value-creating activities, may lead to disastrous consequences in terms of value creation. Information and data of the present work are collected through the analysis of articles from the most authoritative newspapers, including Il Sole 24 Ore, which is the most important Italian business magazine.

The paper is organised as follows. Section 2 describes the main features of the concept of firm economic value. Section 3 depicts Alitalia's history and the characteristics of the airline industry. Section 4 reports the management and corporate 
governance issues in Alitalia, while Section 5 describes the incentive mechanisms employed in Alitalia. The sales of Alitalia and the investigation of the reason for such a poor sale are discussed in Section 6, while Section 7 explains the features from the partnership with Etihad until nowadays. The paper ends up with some conclusions and implications for managers and policymakers.

\section{THE ROOT OF ECONOMIC VALUE: ELEMENTS, DIMENSIONS AND THE EFFECTIVENESS IN DISTRIBUTIONS}

The most important goal for a company is to create value. The term "value", upheld as the main goal of management, concerns the enhancement of resources and current situations and the ability to last through time in relation to the entrepreneurial survival and capacity of growth-oriented towards potential future benefits. The prevailing financial and managerial approach (Myers, 1977; Rappaport 2012) suggests that the value of the company consists of two elements: asset in place and growth opportunities. The first component derives from its real assets in place, independent from future investment strategies. The second element originates from growth opportunities, composed of intangible assets and subject to contingencies, the value of which depends on future discretionary investments. Although the practitioners and the academia have focused on the concept of economic value for a long time, firms' management too often focuses on biased aims due to the misunderstanding on the question for who the firm has to create value. Two approaches discussed for a long time around the firms' goal, suggesting the central role of shareholders (Myers, 1977) or stakeholders (Freeman, 1984). In the meanwhile, Jensen (2001) and Freeman (2001) both highlighted in the same year the importance of combining the two needs, with the two perspectives that seemed to converge towards one single trait d'union: value should be created from the perspective of shareholders, but with the condition (constraint) of satisfying (not to maximize) the expectations of all the other stakeholders.

Nowadays, corporate governance issues are of great relevance to the academic and financial communities. Bhagat and Bolton (2008) evidence how better governance is positively correlated with firms' operating performance. Bauer, Guenster, and Otten (2004) interestingly found that good corporate governance positively influences firms' value and is associated with higher common stock returns. Corporate governance mechanisms represent the tools that lead the management to work for the interest of shareholders (being able to measure the firm's economic value) but under the constriction to create satisfaction for all the stakeholders (common shared value). This role arose because of several opportunistic behaviours, often illegal and sometimes fraudulent, that emerged in the business environment. Many corporate scandals - also referring to situations that, although not against the law, revealed dishonest behaviours - gave the chance to reinterpret them from the economic value perspective, to highlight what was wrong, to obtain implications for managers and policymakers. Value analysis is the theoretical framework of this work. It is the key to interpret cases of opportunism and managerial inefficiency. More specifically, the work of La Rocca (2016), defining the concept of economic value as the corporate purpose and illustrating its components (assets in place and growth opportunities) and dimensions, provides a framework to understand the root of these mismanagement events. In many situations, at the core of potential opportunism there are the differences among the three dimensions of the concept of value: economic value, book value and market value. Economic value shows the real enterprise value in terms of assets in place and growth opportunities and represents the ultimate goal of the company that should be targeted through all the activities and business processes. The book value identifies mainly the value of the assets in place, and it does not consider the intangible resources (growth opportunities) of the company. The market value, instead, represents an attempt by the financial analysts (the financial market) to measure the economic value by taking into account business growth opportunities through the esteem of these intangibles. Therefore, in the case of frictions in the market, as higher asymmetric information, market frictions, contract incompleteness, etc., the differences among these three dimensions can boost opportunism, which is at the core of financial scandals.

The Alitalia case is an example of how the management had a biased goal in managing the firm, focusing on the asset in place and short-run personal benefits instead of sustaining growth opportunities, which feed intangibles in terms of knowledge and skills. Vice versa, bad governance was able to disrupt value damaging at the core of what was a leading Airline company in Europe in the eighties.

\section{ALITALIA'S HISTORY AND THE CHARACTERISTICS OF THE AIRLINE INDUSTRY}

In September 1946, the private company Alitalia (Aerolinee Italiane Internazionali) was founded. After some years of expansion, in October 1957 Alitalia merged with another state-owned Italian airline, LAI (Linee Aeree Italiane). Through this merger, Alitalia became the sole Italian airline. The decades of the 1960s, 1970s, and 1980s were very important for Italian airline. During these years, Alitalia became a leader in the airline industry, increasing its number of customers. Alitalia had a fleet of advanced aircraft, travelling on long-distance routes. In 1960 Alitalia also became the official transporter for the Olympic Games in Rome. For the first time in its history, the company transported over one million passengers per year. Additionally, during the same year, Alitalia introduced a new modern centre for airline pilot training that was highlighted as the best in the world. At the turn of the 1960s and 1970s, Alitalia became the first European airline to fly with an "all-jet" fleet.

Alitalia's business success allowed the company to transport nearly twenty-eight million passengers every year in the 1990s. However, in the last decade of the twentieth century, the Italian airline obtained unsatisfactory economic and industrial results due to labour tensions and excessive investment plans. These disappointing results were mainly due to operational errors caused 
by mismanagement, as the following section will illustrate. Because of the disastrous administration, in 2007 a group of Italian entrepreneurs (through a consortium of entrepreneurs called CAI), supported by the Government, acquired Alitalia. However, after the sale, bad corporate governance persisted until the recent partnership in 2015 with the foreign airline, Etihad, which bought 49 percent of the company's equity. Despite new competent managers and the intention to change the negative trend, the expected results of the Industrial Plan did not occur. The consequence was that Alitalia is still trying to reset poor routines and ways of conducting business.

Alitalia operates in the airline industry, which presents unique features. Based on Table 1 , concerning the strengths and weaknesses of Alitalia and the threats and opportunities from the external environment characterizing the airline industry, it is possible to describe the activities and sources of Alitalia's success before the 1990s and highlight the weaknesses that caused its decline.

Table 1. Alitalia SWOT analysis

\begin{tabular}{|c|c|}
\hline Strengths & Weaknesses \\
\hline 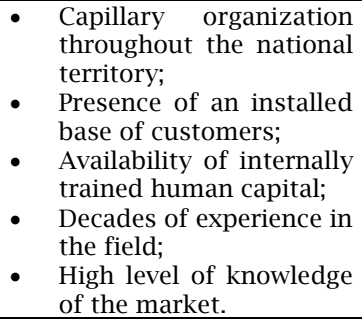 & $\begin{array}{ll}\text { - } & \text { Managerial } \\
\text { incompetence; } \\
\text { - } \quad \text { Too many managerial } \\
\text { structure changes; } \\
\text { - Absence of a long-term } \\
\text { development plan; } \\
\text { - Corporate structure } \\
\text { generating relevant losses; } \\
\text { - Scarce presence on } \\
\text { intercontinental routes. }\end{array}$ \\
\hline Opportunities & Threats \\
\hline 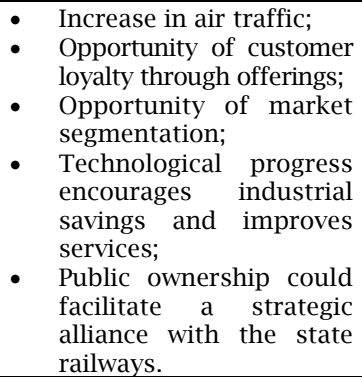 & $\begin{array}{l}\text { - The recent crisis and } \\
\text { terrorist attack reduced } \\
\text { leisure travel; } \\
\text { Too many industrial } \\
\text { costs (such as fuel); } \\
\text { - Diffusion of low-cost } \\
\text { airlines for domestic and } \\
\text { European routes; } \\
\text { Development of high- } \\
\text { speed trains, especially } \\
\text { on the Milan-Rome route. }\end{array}$ \\
\hline
\end{tabular}

The peculiarities and complexities of the aviation sector make it both attractive and risky. The ability to understand fully the dynamics characterizing such a sector is a crucial skill that airline managers should have. Alitalia operated in this particular industrial context, in which managerial skills are essential for firms' value creation.

One of the airline industry's points of strength is the product itself: air travel. In fact, nowadays air travel is often necessary, so the number of clients is constantly increasing. This is especially valid for Alitalia, the sole Italian airline, which has always had an important installed customer base. Therefore, the main task of Alitalia's management was to take advantage of the market opportunities, aside from strengthening and increasing its customer base. In particular, to achieve this goal, Alitalia, like other airlines making up the oligopolistic airline industry, has always exploited its chances to segment the market. Segmentation allowed it to establish different price levels and additional services. For
Alitalia, the widespread organization meant competitive advantages throughout the national territory. Another feature distinguishing Alitalia was the Training Academy, well known worldwide, where human capital was internally trained, ensuring high levels of professionalism, experience and knowledge of the aviation sector.

Alitalia's weak points are explained as follows. First, Alitalia bears the enormous costs necessary in the airline industry. Consequently, the return on investment is risky, since the results might be different from the expected ones, thus creating unpleasant consequences for the enterprise. The main expenditure consists of fuel, which is the biggest cost for all airlines. In fact, a sudden fuel price increase could negatively destabilize the business model. Referring to the case of Alitalia, both the ineffectiveness of managers and the absence of a long-term development plan contributed to a competitive corporate disadvantage.

In addition, in recent years new threats have arisen for airlines. These threats include the global economic crisis, which has greatly reduced free time as well as business and leisure travel. Air travel has also diminished because of new efficient communication technologies, such as telematics conferences, resulting in a decrease in revenues.

On the other hand, Alitalia faces new current opportunities from the development of the air market. For instance, technological progress might lead to considerable savings in energy and fuel. Furthermore, new modern products or services, such as Wi-Fi or other value-added products, might increase future revenues. Moreover, air transport is less expensive nowadays than in the past; thus, a good business plan has great potential to attract new customers. However, despite such growth opportunities, Alitalia has to compete with both the low-cost airlines and the development of high-speed trains.

\section{MANAGEMENT AND CORPORATE GOVERNANCE ISSUES IN ALITALIA}

Through an analysis of the managerial profiles of Alitalia's presidents and CEOs from the early 2000s to the receivership of the company, it is possible to illustrate the most important aspects of corporate governance characterizing the history of the company. It is also possible to understand the logic of the decisions taken by managers, highlighting which features of their work expressed bad governance. In particular, this paper compares the principles of good corporate governance with the decisions taken by the managers of the Italian aeronautic company. Finally, it describes the remuneration plans of Alitalia executives, evidencing their relationship with the business results and comparing their earnings with those of competitors' managers.

The analysis of managers' work (listed in Appendix A) in Alitalia shows notable behaviours that contrast with good corporate governance standards. Specifically, we compared some dominant concepts and sentences that are reported in the main textbooks of corporate governance with the behaviours of Alitalia's managers. Following each sentence is a comment comparing the situation in Alitalia. 


\subsection{Managerial productivity in Alitalia}

The productivity of a manager is a function of knowledge and effort. Since the managers' effort is not observable, we focused on Alitalia's management background and knowledge. Examining the curricula of managers from 2000 to the first government commissioner, we highlighted inadequate managerial skills. Out of nine managers who were in charge of Alitalia during the period of analysis, the only manager with significant expertise in the aviation sector was Fausto Cerreti (in charge from 1996 to 2003). He graduated in aeronautical engineering. He began his professional career in 1954 in the aeronautical company Fiat Avio. In 1969 he moved to Aeritalia, another aeronautical company, where he worked first as the general manager and then as the CEO. After Aeritalia and before moving to Alitalia, he held executive positions in Alenia (an Italian aerospace company) When he left Alitalia, the members of the airline trade association elected him the head of the association. Contrarily, Alitalia's other managers were selected primarily through political connections rather than because of their skills and competencies, despite political connections that do not always provide benefits for firms (Bertrand, 2018). Moreover, most of them had some (not always positive) experiences in public companies. An emblematic case is that of Giuseppe Bonomi, many times alderman and deputy for the political party Lega Nord. He held the role of President for SEA (the company that manages Linate and Malpensa airports in Milan) before moving to Alitalia. Similarly, the special commissioner of the government, Augusto Fantozzi, was a minister and candidate several times at the parliamentary elections for the political centre-left alliance.

\subsection{The airline company value}

Company's value is a function of assets in place and growth opportunities. From the 2000s onwards, Alitalia's management primarily focused on exploiting the inherited assets in place rather than seizing growth opportunities. One of the reasons for which Alitalia missed growth opportunities is due to the low levels of corporate cash held. Indeed, cash holdings represent a crucial determinant for value creation processes (La Rocca, 2016). Too often managers speculated about growth opportunities from alliances or collaborations but never realized them. For instance, in the case of KLM, the Dutch company decided to terminate the contract by paying 250 million euros for damages. Another case is the missed merger with Air France in 2001, blocked by the Italian Government, which will be specified better in Section 6. Moreover, the management was not able to exploit most of the intangible assets, such as human capital. In fact, Alitalia had excellent pilots trained at the academy school in Alghero (in the region Sardinia). In addition, the crew on board had a brilliant reputation due to its competence and availability. Finally, relational capital, built up through years of hard work, quickly broke up because of both the deterioration of stakeholders' relationships (layoffs for thousands of employees, the value of shares falling until the exit from the stock market) and the continuous changes of managers. This alteration did not allow the company either to establish lasting relationships or to rely on long-term development plans.

\subsection{Organizational capital in Alitalia}

The organizational capital is one of three critical success factors to get growth opportunities. The organizational capital, obtained through many years of experience, the human capital, and the relational capital represent the intellectual capital of a company. The organizational capital was not properly exploited in Alitalia. For instance, it did not rationalize the schedules and shifts of the staff. Alitalia was not capable of taking pilots living in Rome from Fiumicino (the airport of Rome) and pilots living in Lombardy from Malpensa (the airport of Milan), spending needlessly on transfers and allowances. According to the newspaper Panorama, until the year 2005, Alitalia paid for between 10,500 and 11,000 hotel rooms every month in Milan to host its own crews, recording peaks of 14,000 rooms per month. The cost was about 100 euros per person each night. The newspaper Il Giornale reported other wastages: a bottle of coke cost Alitalia from 7.50 to 40.00 euros. Data published by the AEA, the European association of carriers, also showed that Alitalia's pilots flew about 14 percent less than those of other major airlines did. They flew on average for 52 hours per month, compared with about 60 hours for Air France, Lufthansa and Iberia (Bracalini, 2008). Another case of wasteful use of the organizational capital is that of Malpensa/Linate. The air traffic of Alitalia, after the crisis in the sector, could not support two $\mathrm{HUBs}^{1}$, but the company used both Malpensa (Milan) and Fiumicino (Rome) as HUBs. Moreover, in Milan, it should have chosen to fly from Linate or Malpensa since it was uneconomical to keep both airports because of the insufficient number of flights to support the two HUBs (Rome and Milan). Nevertheless, political influence overcame the interests of the company, worsening the company's situation.

\subsection{The role of market communication}

Communication with the market not only spreads value, but it also creates value. Alitalia's shareholders were distressed by the continuous announcements to the market about failed mergers and missed purchasing offers. The commissioner Fantozzi provided the market with numerous catastrophic news stories (for instance, he said that the company did not have enough money to pay for fuel). These assertions pressed the unions of workers, forcing them to sign less convenient contracts. Moreover, information about economic and organizational inefficiencies negatively affected the company's intangible assets. Theoretically, good communication with the market allows better relationships with investors, which are extremely important to obtain external financial capital (Tombari, 2018). In the Alitalia case, it was hard to find investors who were willing to allocate their

\footnotetext{
${ }^{1}$ HUB is an airport with flights to lots of different places, where people can arrive from one city or country and get flights to other cities or countries. In this case it represents the core airport where most of the main flights of a company leave and arrive.
} 
funds to a company that was lacking a clear development plan. Consequently, Alitalia continuously asked the state for financial resources. However, the EU rapidly declared the 300-millioneuro loan granted in 2007 to be illegal because it limited the market competition. Hence, Alitalia had to repay it.

\subsection{Interest conflicts and agency costs in Alitalia}

Managers and shareholders have different objective functions (purposes). This may lead to conflicts of interest and agency costs. As evidenced by Berle and Means (1932), firms face conflicts of interest and opportunism problems between managers and shareholders. In Alitalia, such problems were amplified, since the majority shareholder was the Italian state, namely the citizens. The control power was exercised by the Government, which unfortunately protected different interests from the safeguarding of the investments made. Political instability led to continuous changes in management, disregarding the rules of managerial efficiency and effectiveness. The Government did not focus on corporate value growth but sought to pander to pressures from the external environment. An example is the above-mentioned case of Malpensa/Linate, in which, despite it clearly being economically unworkable to maintain both airports, no one acted to respect the principles of organizational efficiency. Another example is the failed merger with Air France, a foreign partner that was not appreciated by the Italian Government. The missed sale to Air France, the offering of which was much more advantageous than others, is an emblem of mismanagement effects. It is possible to assess the presence of a peculiar conflict of agency: on one side Italian rulers, together with their own trust managers, and on the other side Italian taxpayers, shareholders, employees and bondholders of Alitalia. The Government, rather than looking at the company's value, pursued different interests, such as the preservation of "nationalization" (then unpreserved). This is a case in which politicians exploited their influence on the company in order to obtain political advantages, as evidenced by Ferramosca (2018). Significant in this regard was the establishment of a direct flight from Albenga to Rome Fiumicino when the Hon. Scajola was Minister of the Interior (Anonymous, 2008). The flight recorded a maximum number of eighteen passengers, and it was deleted as soon as Scajola left his office. The Albenga Airport is only $50 \mathrm{~km}$ from Genoa airport; the aircraft operating on the route was an ATR 47, and for 3 days per week it was parked. The cost of the ATR 47 for Alitalia was about 100,000 euros per week. Hence, the fact that a minister did not like to travel by car from Albenga to Genoa cost the company a remarkable amount of $5,200,000$ euros per year.

\subsection{Authority and responsibility in Alitalia}

Intellectual capital management is a function of authority (decision-making power) and responsibility. The managers of Alitalia had broad decision-making power over ordinary operations, while the political interests limited their power over extraordinary operations. For instance, the management wished for the merger with Air France, but, as mentioned, the operation failed because of the Government's influence. Moreover, the management did not pay particular attention to minority shareholders, but it had a privileged relationship with politicians. Meanwhile, the politicians tried any possible way to limit the liability of directors, succeeding during the stages of Alitalia's sale. For instance, through the enactment of the law decree n. 134/2008 (published in the Official Gazette no. 201 of $28^{\text {th }}$ August 2008) the Council of Ministers undertook the privatization of Alitalia, excluding liability for the behaviours of directors and auditors of Alitalia and all other firms regarding all acts carried out from 18.07.2007 to the enactment of the decree. However, this law was subsequently withdrawn. Nevertheless, the mingling of interests between political power and managers, who were responsible for their behaviours with negative results, is undeniable.

\section{INCENTIVE MECHANISMS EMPLOYED IN ALITALIA}

To align the interests of the managers with those of the ownership, it is important to exploit incentive mechanisms, which should deter executives from engaging in opportunistic behaviours. Incentive mechanisms consist of providing managers with direct incentives to engage in positive behaviours through economic rewards, such as stock options or stock grants, when they achieve certain objectives. Indeed, according to the agency theory, the efficiency of capital markets and the effectiveness of the information system prevent managers from opportunistic behaviours (Brogi, 2016; Singer \& Sirianni, 2015).

In Alitalia, it is possible to note that the salaries of the managers were completely incoherent with the company's performance. The aviation company achieved several negative results (see Figure 1). Its stock market value, as reported by the journalist Eugenio Scalfari, decreased from about 10 euros per share in 2001 to only 1.57 euros in 2006 (Scalfari, 2008). Notwithstanding these negative results, between 2004 and 2007, Alitalia surprisingly liquidated wages for about 6 million euros to the former manager, Giancarlo Cimoli. In 2005 Cimoli cashed a salary of about 2.8 million euros, corresponding to 6 times the salary of the CEO of Air France and 3 times that of the CEO of British Airways. 
Figure 1. EBIT performance of Alitalia between 1998 and 2007

Earnings Before Interests and Taxes (in tens of millions)

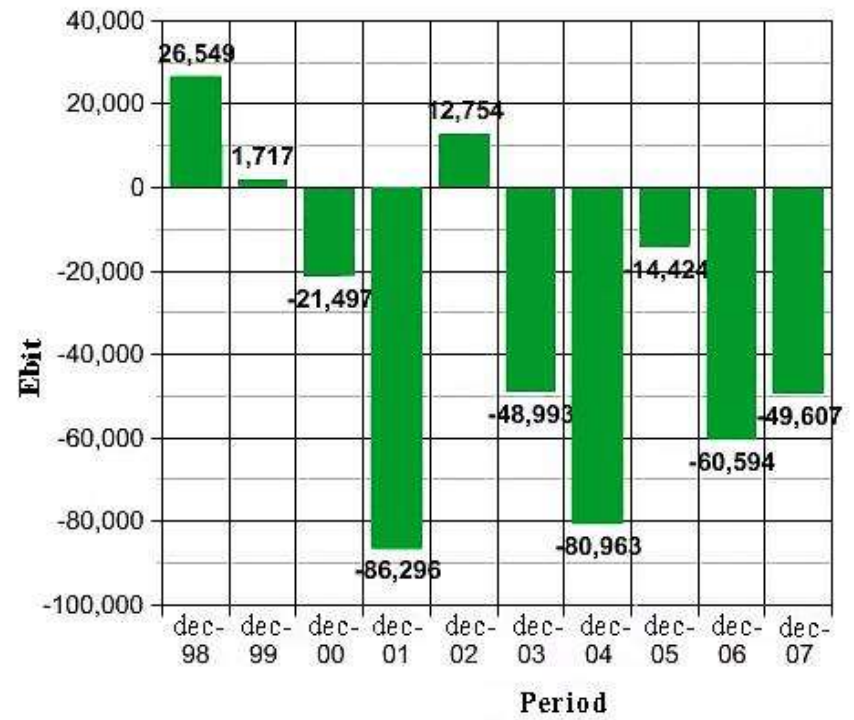

Source: Alitalia's balance sheets

These events attracted the attention of consumers. As reported in the article "Crack vecchia Alitalia, i risparmiatori portano in tribunale gli stipendi d'oro", published in the newspaper Corriere della Sera on 11 October 2009, the minority shareholders, represented by the lawyer Giovanni Tognon, decided to take legal action. In addition, according to the statement of the lawyer, in 2003 Mengozzi's wages amounted to over 1 million euros. In 2004 Cimoli's salary was 1,522,000 euros, while the Board of Directors' wages were 277,000 euros altogether. In the following year, the Board of Directors received the same salary as in the previous year, while Cimoli's salary almost doubled (2.7 million euros). Cimoli cashed 1,540,000 euros in 2006, while the Board of Directors earned 150,000 euros. For the first two months of 2007, Cimoli earned 131,000 euros, while the Board of Directors cashed 219,000 euros. Maurizio Prato replaced Cimoli and received 350,000 euros from March to December. During these years Alitalia reported significant economic losses as Cimoli said: "Alitalia more flies and more losses". As shown in Table 2, the top managers of the competitors had much lower remuneration, taking into consideration both salaries and bonuses. Moreover, unlike Alitalia, other airlines generated profits.

Table 2. CEOs' monthly salaries, referring to the year 2004, of some major airlines in the EU

\begin{tabular}{|l|l|l|l|}
\hline Company & \multicolumn{1}{|c|}{ Profit/loss } & \multicolumn{1}{c|}{ CEO } & \multicolumn{1}{c|}{$\begin{array}{c}\text { Monthly } \\
\text { salary }\end{array}$} \\
\hline Air France & $98,000,000$ & J.C. Spinetta & $29,583,00$ \\
\hline KLM & $261,000,000$ & Leo Van Wijk & $45,143,00$ \\
\hline $\begin{array}{l}\text { British } \\
\text { Airways }\end{array}$ & $333,000,000$ & $\begin{array}{l}\text { Rod } \\
\text { Eddington }\end{array}$ & $64,727,00$ \\
\hline Alitalia & $-813,000,000$ & $\begin{array}{l}\text { Giancarlo } \\
\text { Cimoli }\end{array}$ & $190,375,00$ \\
\hline \multicolumn{2}{|c|}{ Source }
\end{tabular}

Source: article "'Alitalia falliva, i manager s'arricchivano' piccoli risparmiatori: ecco le cifre", published on 10 October 2009 in the newspaper Il Messaggero.
"Surprisingly - as assessed by the lawyers Tognon and Fiorillo - in 2005 the Board of Directors doubles the salary of Cimoli, who reaches 2.791 million euro per year, although Alitalia records substantial losses. It is clear how CEOs and the Board of Directors have always been interested in preserving their roles, disregarding the health and the productivity of the company. This happened because their wages and the maintenance of their position have always been 'guaranteed' through the tacit approval of the Italian Government" (Solleviamoci, 2009). With regard to disproportionate wages, the opposite case of good governance implemented by Cathay Pacific (the Hong Kong airline) is emblematic. Indeed, the new Industrial Plan 2017 of Cathay Pacific reports the dismissal of the most waged and unproductive managers, saving 64 million dollars per year. Perhaps Cathay Pacific learned from Alitalia's mistakes since management courses teach that good corporate governance policies are difficult to identify, but the effects of mismanagement are easy to recognize. The behaviour of Alitalia's management had criminal consequences. In fact, several proceedings are now pending with charges of bankruptcy to dissipation or distraction. In September 2015 the Court of Rome at first instance sentenced for bankruptcy 4 former managers, including Giancarlo Cimoli (President and CEO of Alitalia from 2004 to 2007), to 8 years and 8 months in prison and Francesco Mengozzi (AD from 2001 to 2004) to 5 years in prison. The Court considered decisions taken from 2001 to 2007 that were "abnormal or unjustified under the economic and managerial point of view", causing losses of more than 4 billion euros. Former managers were also sentenced to pay more than 355 million euros to Alitalia's group companies that were poorly managed, their shareholders and their savers (De Santis, 2015). In conclusion, managerial political connection brought about a decrease in corporate performance. 


\section{THE SALE OF ALITALIA}

On 1 December 2006, the Italian Government, led by Prime Minister, Romano Prodi, decided to sell Alitalia's majority of shares. The company reported losses of over 380 million euros at the end of 2006 , as evidenced by its official statement. The main purchase offers were the following:

1) Air One (supported by Bank Intesa), an airline company headed by Carlo Toto, a renowned builder who invested in Autostrade Italiane (the company managing Italian highways) and financed many important political parties. However, Air One participated in the offering despite its ruinous accounting statement, reporting losses equal to three times its net capital. This case evidences conflicts of interest between the buyer (Carlo Toto) and the seller (the State);

2) Air France, the French airline company, which offered to pay 3 billion euros and to bear the entire debt position. However, the plan of Air France also included approximately 2,150 dismissals; thus the unions of the workers opposed the negotiation. Moreover, the hostility of the new Berlusconi Government, which took power just after Prodi's Government, towards the acquisition from a foreign partner pushed Air France to withdraw its offer. Nevertheless, Air France's proposal was the most convenient one, as assessed by the former Economy Minister, Vincenzo Padoa Schioppa, in an interview on the Italian news channel RAI TG3. In this case, the owner (the State), not being independent, would have delegated the choice to managers able to assess the economic suitability of the operation.

Moreover, technical and financial experts clearly evaluated Air France's plan as the most suitable one, as highlighted by Boursier (2008). Therefore, Alitalia missed a significant opportunity because of the strong influence of the Government on the negotiations. In particular, rather than growth opportunities, Alitalia needed recovery opportunities.

Therefore, the outcome of the negotiations was determined not by the economic advantage but unfortunately by political factors. Once more, the ownership structure of Alitalia created inefficiency, damaging its value creation. When in January 2007 Prodi's Government failed, the new Berlusconi Government decided that a consortium of Italian entrepreneurs should acquire Alitalia. During those weeks, the company was losing 3 million euros per day, while the title was quickly falling on the stock market. For these reasons, Premier Berlusconi applied to the outgoing Government for a 300 million euro loan to increase the equity and save Alitalia from bankruptcy. However, formally, the Government granted this loan for "public order reasons", thereby evading the European rules on State aid. This additional loan was very risky for Alitalia since the European Union could force its repayment. In fact, as expected, sometime later Alitalia had to return the loan. From a theoretical point of view, the use of debt often increases managerial discipline. However, in Alitalia, this benefit was irrelevant, since the creditor (the State) was also the owner of the company.

Nevertheless, Alitalia continued to lose economic value. Moreover, the Government enacted a decree derogating laws about state divestitures to overcome the emergency. The decree suspended mandatory information about the transparent and competitive public procedures that listed companies every year must communicate to Consob (Commissione Nazionale per le Società e la Borsa). As a result, the stock market suspended the title of Alitalia because of this information opacity. Furthermore, the Government guaranteed Alitalia its financial support for the next 12 months to allow the Board of Directors to approve a financial statement reporting 495 million-euro losses and over billion-euro debts. The loan, the decree and the financial coverage represented managerial choices taken by the Government by abusing its authority, in the complete absence of accountability, disregarding important corporate governance rules. Any negative consequence of such choices would have influenced not the Government but the owner of Alitalia, that is, the State, or rather the citizens.

Having solved the upcoming problems, the Government tried to create the above-mentioned consortium of Italian entrepreneurs, appointing Corrado Passera, CEO of Bank Intesa, as an advisor. His task was to find entrepreneurs who were interested in the project. Though the advisor should be impartial, both Bank Intesa and Air One (which had important banking relationships with Bank Intesa) belonged to the consortium. Therefore, it is possible to evidence conflicts of interests between the advisor, buyer and seller.

Besides, the President of the consortium, named CAI (Compagnia Aerea Italiana), was Roberto Colaninno, former manager of Telecom (an Italian telephone company), who obtained no particular industrial result. However, it is not essential for good corporate governance that shareholders have managerial skills. In fact, an advantage of the principal-agent separation is to entrust the governance to competent managers. It is interesting to notice that all the investors involved had selfinterests with the State. Which kinds of interests were they? Reported below are some of the personal interests of the entrepreneurs: 1) Benetton was allowed to increase highways' tolls for the next thirty years, with no obligation to make new investments or to increase the quality of the service; 2) Ligresti was a potential contractor as Milan EXPO's builder; 3) Toto saved his company from bankruptcy, while Bank Intesa, in turn, saved its banking interests with Air One; 4) the Riva family, owner of ILVA (the biggest Italian steel producer company), might have received something in return considering that the environmental regularity of the company depends on state regulations about industrial pollution. 
Figure 2. Some of the interests involved

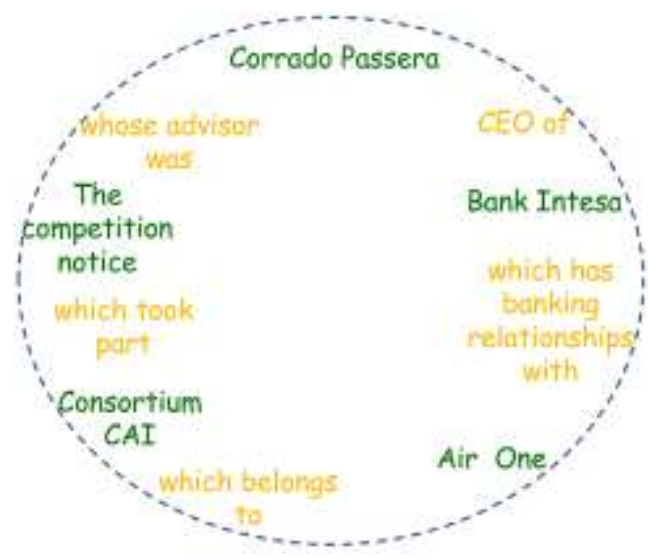

Moreover, firms providing outsourced services to Alitalia failed, and such services were carried out too expensively by companies in a relationship with CAI's members. In this circumstance, mismanagement is also evident because the transaction costs were not minimized, as suggested by the transaction cost theory of Coase. For instance, it assigned the aircrafts' maintenance to a consortium led by Meridie SpA, the minority shareholder of which was $\mathrm{CAI}$; then, it assigned cargo services to Alcide Leali, partner of some of CAI's partners. It is thus clear how such industrialists focused on self-interests, disregarding the maximization of Alitalia's value. Shareholders should be inspired to undertake monitoring activities to minimize opportunism (agency theory) while in Alitalia the ownership structure was at the core of the problems. Despite conflicts of interest, the negotiations continued. Bank Intesa found all the necessary investors and drew up the financial plan. The core of the project consisted of giving all the debts, liabilities and redundant employees to a "bad company" owned by the State. Meanwhile, through the assets in place, the Government founded a new company (merging with Air One, which gained safety from financial constraints) with the purpose of restoring Alitalia.

Therefore, at the end of the negotiations, Italian taxpayers had to pay Alitalia's debts due to past mismanagement. As highlighted by Dittmar and Marth-Smith (2007), it is more likely that managerial choices are mistaken when the money does not belong to the decision-makers. This is exactly what happened in Alitalia's case. In addition, the merger with Air One meant a violation of antitrust rules because of the reduction in the market competition. Nevertheless, through a specific decree, the Government suspended the antitrust rules for Alitalia and discharged from illegal liability the previous directors, managers and auditors of Alitalia. This decision represented a serious limitation of corporate responsibility, ignoring a fundamental mechanism of value safeguarding. Indeed, restricting the legal system of enforcement implies limiting an important corporate governance institutional mechanism.

\subsection{CAI management}

The Government finally reached an agreement with the consortium at the "modest" price of 1 billion 52 million euros. The agreement also included that the majority of the company could not be sold to a foreign partner for the next 4 years. The unhappy result was that the preservation of the Italian ownership, which was the main reason prompting the Government to propose the consortium, was not definitively guaranteed. Moreover, Air France initially excluded - took part in the consortium. The Government assigned the task of estimating the selling price to Bank Leonardo (of which the shareholders were, among others, some of Alitalia's new buyers, such as Ligresti, Benetton and Tronchetti Provera). As expected, Bank Leonardo's calculation underestimated the value of Alitalia, the true economic value of which was probably much more than the final selling price.

The final selling price was barely 252 million euros in cash paid, while the remainder was the assumption of debts. After pressing dialogues, the Government reached an agreement with the unions of workers too. These were not wholly satisfied, but, having no other option, they, at last, decided to accept. Workers' unions were important stakeholders; their dissatisfaction disregards a fundamental rule indicated by Jensen (2001) and Freeman (2001): value creation means maximizing shareholders' value by first satisfying stakeholders' expectations.

The Government declared Alitalia safe. From now on the hope was that Alitalia had solved all its industrial problems and would return to being a brilliant airline company. Instead, unfortunately, new Alitalia did not improve. During the following months, the number of passengers decreased dramatically, causing losses similar to those of the old company. The year 2009 reported 262 million euro losses, as highlighted by Boursier (2010). Too many flights did not have the minimum crew on board, while too many delays and inefficiencies resulted in unsatisfied passengers. The company did not recover from the industrial point of view, despite CAI acquiring only the "good part" of Alitalia. The financial conditions were optimal to recover from industrial difficulties since Alitalia was not totally bought out (as Air France would have done), but it was partially purchased by CAI, which acquired only the assets in place (and not the debts). Nonetheless, the mismanagement continued with the next CEOs and presidents too. Perhaps they did not really care about the company's economic interests. The CEO, Rocco Sabelli, and the President, Colaninno, failed in their task to make the company competitive again. This was also due to the persistence of past managerial errors, such as the presence of conflicts of interest. For instance, the HUB was mistakenly settled in Fiumicino (Rome) instead of Malpensa, (Milan), because ADR, a company controlled by Benetton (CAI member), managed the airport of the capital. Another example concerned the commitment of the maintenance of the thermal power to the enterprise Natuna, owned by the Angelucci family (another CAI partner). The Government chose the management of Alitalia, which was practically administered by a kind of insider ownership, without focusing on value maximization goals. A year-and-a-half after the arrival of CAI, the results were not the expected ones: the debts were higher than the expectations. The number of layoffs and redundant pilots was 
more than the number agreed with workers' unions. The industrial hopes had failed. Moreover, Alitalia rented aircraft from Air One for flights, spending 48 million euros per year, while Air One spent 42 million to lease them (Boursier, 2010). In conclusion, bad governance continued even after CAI's acquisition.

\subsection{The old Alitalia}

What happened to the old indebted Alitalia? The Court of Justice registered Alitalia to an extraordinary bankruptcy judicial procedure for large companies. The Government designated Augusto Fantozzi as Commissioner; his task was to liquidate the company's property goods (lands, paintings, holdings, buildings, and others). A few days later, Fantozzi declared that the company's cash was "barely" 50 million euros, but the reality was different: the liquidity of Alitalia was about 200 million euros. Another case of disinformation occurred when Domenico Lellis, CFO of Air One in an interview for the television programme Report admitted that the financial situation of Air One was bad (Boursier, 2010). The CFO also said that he did not exactly know which budget items were negative because he did not work in the accounting offices. It is interesting to note a similarity with Jeffrey Skilling, former CEO of Enron, who claimed not to know the reason why the company had a negative accounting situation since he was not concerned with accounting. In the same interview, Lellis announced that the company was still expanding, but this was not true. Therefore, Lellis risked giving the market untrue information, which was potentially harmful to the company, since the market value was likely to be different from the real economic value. The above-mentioned case shows how asymmetric information and managerial opportunism increase the market value despite the real economic value not changing. Thus, the dimensions of value are misaligned.

Figure 3. Stakeholders' consequences due to bad governance

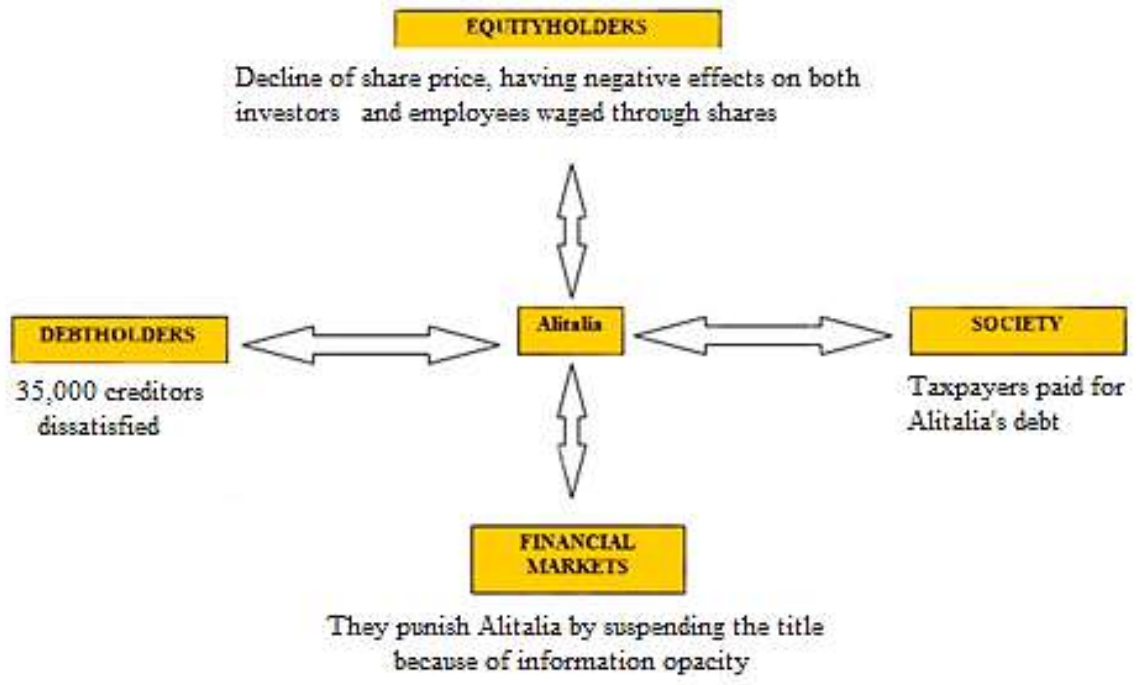

Figure 3 shows the consequences for Italian taxpayers of the disastrous management of Alitalia: 1) 9,000 redundancies and 7 years of layoffs; 2) dissatisfaction for 35,000 creditors; 3) a loss of share value, resulting in an economic loss for employees waged through shares. The stakeholders were dissatisfied.

In July 2011, three new Commissioners, chosen by the Government, replaced the Commissioner Fantozzi. Unlike Italy, in all other states the Court of Justice names Commissioners, even for public companies. Before his substitution, Fantozzi carried out a "responsibility action" against the previous managers (Cimoli and Mengozzi) and Presidents (Libonati, Police, Spinetta, Prato, and Bonomi). He accused them of "mismanagement" because they failed to work in the economic interests of Alitalia, producing irregularities that brought about the collapse of the company. Consob fined Antonio Baldassarre, the former President of the Italian television RAI and of the Constitutional Court, for disseminating false and misleading information to the market. In fact, he communicated incorrec financial data regarding a consortium (led by him) that was potentially interested in Alitalia's acquisition.

Conflicts of interest persisted: the new Commissioners relied on the expert Ernst \& Young Company to quantify Fantozzi's revocation actions, despite the fact that Ernst \& Young should have returned 939,000 euro to the old Alitalia. On 31 July 2012, the new Commissioners presented a new responsibility action, including only 5 directors and asking for reimbursements for "only" 82 million euros instead of the 3 billion requested by Fantozzi.

\subsection{Consequences of CAI's mismanagement}

During the first six months of 2013, Alitalia's balance was still negative: the losses rose to 294 million euros. The company economized through low-cost rentals of Romanian aeroplanes and by saving fuel, boarding the minimum number of litres required by law. Pilots were rewarded if they saved fuel. However, some of them stated that it was very risky behaviour (Gabanelli, 2012). Alitalia's industrial 
problems during this period were also due to the world financial crisis and the strong competition with low-cost airlines, preponderating on shortdistance routes. However, other important airlines, such as the German Lufthansa, also reported losses with regard to short-distance routes. On the other hand, their noteworthy profit margins were on longdistance routes, which had been significantly reduced by Alitalia. Therefore, Alitalia's main difficulties were still due to wrong managerial decisions.

Subsequent to CAI's mismanagement, Alitalia had to be recapitalized, as required by law, since the losses exceeded one-third of the total shares. 2013 was also the year, in which a foreign partner could acquire Alitalia, losing the "nationalization" that Berlusconi's Government wanted to save. The bad corporate governance during and after the sale did not solve the past problems. Moreover, a foreign company could acquire the majority of Alitalia's shares, paying much less than the 3 billion euros that Air France promised in 2008.

To sum up, Alitalia's decision-making management was disastrous. Chairman of the Board and CEOs with executive power (and Commissioners after the receivership), whose profiles are in detail described in Appendix A, completely ignored the rules of good corporate governance because of both managerial incompetence and conflicts of interests. Who took the responsibility for this great defeat? The Government tried to remove the consequences of mismanagement, presenting - on 2 October 2008 - an amendment (later withdrawn) to the Marzano decree legislating on big companies recovery. The amendment excluded penal sanctions for bankruptcy caused during insolvency situations (and not business failure situations). It implied that it could not punish the managers of Cirio and Parmalat too. Again, it bound external corporate governance mechanism incentives.

Nevertheless, the investigations of "mismanagement" continue, but the waste of time affected Alitalia's 35,000 creditors negatively (Gabanelli, 2010). In fact, those who cashed their credits during insolvency should return them because of the revocation action, but no one could force them to give the money back after five years. Hence, the consequences of bad governance were irreparable.

\section{FROM THE PARTNERSHIP WITH ETIHAD TO THE PRESENT}

As the above showed, mismanagement also appeared during CAI's governance, which evidenced the same managerial mistakes as occurred in the 1990s and the 2000s. The bad governance exerted inevitable adverse effects on the company's value. As a result, a strong foreign partner became important to raise Alitalia from the financial and industrial points of view. Practically, the arrival of a foreign partner was delayed for some years. If it had happened earlier, the taxpayers would have avoided wasting a billion euros. The Mediobanca Mbres study office calculated that, from 1974 to 2014, Alitalia squandered 7.4 billion euros of public money.

\subsection{Etihad's acquisition}

The entry of Etihad into the company was fundamental for Alitalia's relaunch. The aim was to forget the bad corporate governance characterizing the last twenty years and to focus on the intention to develop virtuous management.

The key to understanding good governance actions is the resource-based view (RBV). The RBV emphasizes the importance of firms' specific unique and distinctive resources, capabilities and competencies for the purpose of acquiring and maintaining a durable competitive advantage. Another important aspect of the RBV is the combination of resources, which, according to many authors (e.g., Barney, 1991), can be distinguished into three main categories: 1) physical capital, 2) human capital (skills, knowledge and managerial expertise) and 3) organizational capital. These resources generate value, whether they exploit the assets in place and the growth opportunities or neutralize threats, reduce costs and increase revenue. Competitive resources should also develop new resources and capabilities to keep a competitive advantage.

Concerning the role of Etihad in the partnership, it is possible to identify some main phases. The Arabian Etihad Airways (with significant cash resources), on 8 August 2014, announced the purchase of 49 percent control of Alitalia. Alitalia became a member of a partnership consisting of 8 airlines with important know-how in the aircraft industry. The industrial goal was to turn Alitalia into a 5-star airline within 5 years. The new Alitalia, the company name of which was SAI (ATA Italian Airlines Inc.), was led by the new chairman Luca Cordero di Montezemolo and Duncan Naysmith (from Etihad) as the Chief Financial Officer.

The Industrial Plan adopted in 2015 expected a return to profits in 2017. The programme announced by President Montezemolo finally intended to change the negative managerial trend. For instance, Alitalia solved a past problem by developing long-distance intercontinental routes and new routes and exploiting the synergies of the Etihad Group. This managerial policy confirms how taking advantage of group synergies and organizational capital is an important aspect of seizing growth opportunities and a resource difficult to imitate. With this regard, Alitalia strengthened its assets in place, which represent an important driver of value and its growth opportunities by relying on the relational capital of the new group. New onboard services for customers were expected to improve matters by introducing Wi-Fi on-board, improving the catering and producing new more comfortable seats. A new marketing approach focused on customer satisfaction: Alitalia introduced the Customer Excellence Training Academy to train the staff in customer service. Another important objective was to achieve the inevitable rationalization of costs without reducing the quality of services, as suggested by the transaction cost theory of Coase. This happened by developing synergies with the Etihad Group partners. For instance, the unexpected positive boom due to collective bonds emitted with the group allies proved how the unification of finance and purchasing is convenient for all the partners in the 
medium term. It also showed that it is possible to use debt properly, differently from the situation in the past. The arrival of a new governance team was the main break from the past. Many of the former mistakes were due to the managers since the latter was chosen for their political preferences rather than for their skills. The Australian Cramer Ball, who successfully managed Jet Airways (24 percent owned by Etihad), was the new name after too many years when Presidents and ADs had scarce skills. He was a manager who knew the international air markets well. There were also other competent new entries: Alessio Vinci, Communications Director, Roberto Tundo, Head of Information Services, John Shepley, Strategy and Planning Director, and Aubrey Tiedt, Head of Customer Services (who had the idea of the Training Academy). Foreign management was also essential to reduce conflicts of interest and agency costs.

\subsection{Alitalia performance after Etihad's acquisition}

However, despite the ambitious project (new investments, new routes, new services, new management, a focus on customer satisfaction and, more generally, the intention to implement good corporate governance), the main problem in this phase was that the market did not correctly perceive the changing approach. The inevitable result was that the company's performance was not as expected. This consequence demonstrates how good corporate governance ought to deal with informational asymmetries that may affect value creation negatively.

Three years after Etihad's acquisition, despite several improvements, Alitalia did not achieve the estimated results, especially from the economic point of view. The business policies planning to reverse the negative trend were not enough to revive the company from all the difficulties resulting from historical mistakes. It was certainly challenging to lead the company from the disastrous starting point - due to unsuccessful management over the last twenty years - to the Industrial Plan's forecasts. It would probably take more than two years to complete the economic turnaround. In March 2017, President Luca Cordero di Montezemolo resigned. At the same time, Cramer Ball gained a contractual improvement: in the event of resignation or dismissal without a proper reason, his severance payment was extended from two to five months. Moreover, his wage would not have been affected by the cost reduction planned for other employees. This was obviously in contrast to the good corporate governance rules and the changing tendency that Alitalia planned to realize. On the contrary, Alitalia should have reduced the managerial wages, as the Hong Kong Airline Cathay Pacific did properly, to gain important savings. This case showed how the old managerial errors persisted. Therefore, the presence of competent managers did not stop the wrong behaviour in conceding wages and severance payments that were disproportionate to the economic-industrial results. The new Industrial Plan projected by Cramer Ball and approved by the Board of Directors in March 2017 aimed to return the company to profit in 2019. It revised the business model by aligning Alitalia with the business policies of low-cost companies to recover the market shares.
The new Industrial Plan also provided a significant and foreseeable reduction of the industrial costs, especially the staff costs through 2,000 redundancies and an average 30 percent reduction in salary costs. It was necessary to reduce such fixed costs because of the 20 years characterized by assumptions that were too often unnecessary. However, after this decision, the workers rejected the Industrial Plan through a referendum on 24 April. As a result, the Italian Ministry of Economic Development decided to appoint new Government Commissioners. Luigi Gubitosi, a skilled manager, former Rai (Italian National television) CEO and Fiat manager. Enrico Laghi, an expert in crisis companies and commissioners of the above-mentioned ILVA. Stefano Paleari, an aviation expert and currently leader of Human Technopole, a scientific research centre that will be located in the Expo area of Milan. The new commissioners seem to be suitable for the important role that they will play. However, like their predecessors, they will face a critical economic and industrial situation. The Government also financed Alitalia with a 600-million-euro loan to cover the unavoidable expected losses. Nevertheless, Alitalia will hardly be able to repay this loan, for which the interest rate is 10 percent (Massaro, 2017). On 18 May 2017, a public procedure for a new Alitalia sale was published.

In conclusion, it is important to highlight that poor management had negative consequences for the company's life up to the point that nowadays Alitalia still suffers from such consequences.

Some inappropriate managerial behaviours also occurred after Etihad's acquisition, such as the extension of the severance payment for Cramer Ball (before he left Alitalia) or the announcement of too optimistic expectations (which misalign the economic value with the market value), for which god corporate governance rules have partially been disregarded, even after 2015. The hoped turnaround from the past, especially through the arrival of new managers, has not been achieved effectively. This shows how mismanagement might have disastrous consequences for business value until it definitively compromises a company's capacity to create value. Indeed, the Alitalia case evidenced how the efforts of competent managers desiring to reverse the negative route were not enough to recover the company's performance. The effects of previous mismanagement prevailed until they had almost completely removed the opportunities for business value regrowth. One of the causes of such lost regrowth opportunities was the crucial harmful role played by the Italian Governments during the years of our analysis, whose influence on the airline company did not have beneficial effects, as evidenced in Sections 4 and 6.

\subsection{Future perspectives}

However, there are important differences between what was wrong in the past and what was wrong at the time of the Etihad partnership. While in the past there were problems of poor corporate governance, at the time of the Etihad turnaround, the main problem was that it was a period of tremendous business changes in the airline market. Reorganizing the business in this period was a major issue considering that, in terms of strategy, the 
competition was increasing. Big players are copying the business model of low-cost firms: the prices, even of continental routes, are falling, and the expectation is consolidation through acquisition. A recent newspaper article suggested that low-costs airlines' economic convenience compared with that of larger airline companies is gradually decreasing, especially when considering costs that are not included in the flight ticket, such as those associated with services at or transportation from or to the airport (Brigatti, 2017)

It is expected that the market, in the long run, will involve around 5 to 7 large players sharing the cake of 700 billion customers in the air transportation industry. Consequently, failures or mergers are likely to occur in the coming years. Many companies of any size (i.e., Air Berlin and Monarch) are experiencing trouble, although the business model is supposed to be the right one since they face difficulties in gaining economies of scale, which are essential to offer low prices. Even Ryanair and EasyJet, despite their continuous annual growth, have recently encountered some difficulties. Therefore, industrial problems, to different extents, currently concern both low-cost and other companies. In light of the above, the actual problem of Alitalia, rather than bad governance, is facing a market in which the competition is becoming too fierce. To deal with this challenge, airline companies started making alliances (Pavlovic \& Babic, 2018). In this industrial context, Alitalia is nowadays in negotiations to be sold to the German company Lufthansa.

Nowadays, it is particularly tough to select appropriate strategies to gain a sustainable competitive advantage. Companies should take advantage of the opportunities resulting from changes in the airline sector. However, this challenge is more difficult for Alitalia, considering that the company is still dealing with economic difficulties due to past mismanagement. Therefore, Alitalia will face both the actual economic difficulties and the ongoing dynamicity and complexity of the airline environment, in which firm-specific resources are crucial to grasp the upcoming opportunities due to the dynamic context. The purpose is somehow to be one of the winners of the expected intense competitive battle.

\section{CONCLUSION}

The present article has analysed how bad corporate governance affected Alitalia's economic value. It has examined the work of the managers during the 2000s, evidencing how crucial weaknesses in the administration system negatively influenced the economic and industrial performances of the company. In particular, the majority of managers lacked adequate managerial knowledge regarding the airline sector. They also had scarce incentives and effort. Too often, appropriate mechanisms of responsibility and accountability did not support the authority of the decision-makers. During the mismanagement period, the company missed important growth opportunities. For instance, it did not properly exploit Alitalia's significant human capital, representing its greatest success factor. Moreover, information opacity was harmful to the company, because a strong investor relationship is important both to create value and to align the economic value with the market value and the economic value. Furthermore, it did not apply incentive mechanisms: the managerial wages were not proportionate either to the financial results or to those of competitors' managers.

Even in the stage of the sale to the Italian consortium CAI, bad governance problems emerged. The missed acquisition by Air France represented the loss of a significant recovery opportunity. Entrepreneurs belonging to the Italian consortium had personal interests with the Italian State. Therefore, they did not carry out monitoring activities, resulting in managerial inefficiencies. The poor performances of the directors brought about dissatisfaction among the stakeholders too. The Government actually led the company, creating a kind of insider ownership. Moreover, the Government tried to discount criminal responsibility for managers, despite an effective accountability system being fundamental to achieving value maximization goals. After the mismanagement period, Etihad Airways acquired 49 percent of Alitalia's shares. The Arab partner tried to relaunch the company through new skilled managers and the Industrial Plan approved in 2015. However, despite the efforts to change the negative trend, the company did not achieve the expected goals. The employees rejected the next Industrial Plan approved in March 2017. Now Alitalia will be sold again. Bad governance has had such a negative impact on the corporate value that it has limited Alitalia's prospective capacity to create value. However, while in the past the problem of bad governance hit at the core of Alitalia, today its main problem is being able to turn the business around in such a fierce market competition, in which it is mainly unknown what the key factor of success will be.

To sum up, between the 1990s and the 2000s, and sometimes even in recent years, Alitalia wholly disregarded the internal and external corporate governance mechanisms safeguarding the company's capacity to create value. Conflicts of interest and managerial opportunism prompted the managers to ignore the rules of good governance. The study validates the importance of good corporate governance on firms' performance, as evidenced by Bhagat and Bolton (2008). Moreover, it also practically confirms the corporate governance rules theorized by prior managerial studies. However, it also has some limitations, as it studies the phenomenon of bad corporate governance in the particular single (Italian) context in which Alitalia operates. Italy is a bank-based country with low investor protection and high problems of asymmetric information between firms and their investors. Moreover, in Italy politicians have an important influence on large companies. The unique characteristics of the Italian airline company and the Italian national context provide originality to the present work, but at the same time represent a restriction in terms of generalizability of results, for which future analysis in different contexts could bridge this gap.

In conclusion, the case of Alitalia is very important to understand the consequences of mismanagement. Corporate governance is difficult to define, but it is easy to recognize when it shows its effects. In Alitalia's history, such effects are definitely appreciable. 


\section{REFERENCES}

1. Anonymous. (2008, August 17). Scajola e il milione di euro stanziato per il volo Albenga-Roma. Corriere della Sera. Retrived from https://www.corriere.it/politica/08_agosto_17/scajola_albenga_roma_7674e1a0-6c3311dd-9087-00144f02aabc.shtml?refresh_ce-cp

2. Barney, J. (1991). Firm resources and sustained competitive advantage. Journal of Management, 17(1), 99-120. https://doi.org/10.1177/014920639101700108

3. Bauer, R., Guenster, N., \& Otten, R. (2004). Empirical evidence on corporate governance in Europe: The effect on stock returns, firm value and performance. Journal of Asset Management, 5(2), 91-104. https://doi.org/10.1057/palgrave.jam.2240131

4. Berle, A., \& Means, G. (1932). The modern corporation and private property. New Brunswick, N.J., USA: Transaction Publishers.

5. Bertrand, M., Kramarz, F., Schoar, A., \& Thesmar, D. (2018). The cost of political connections. Review of Finance, 22(3), 849-876. https://doi.org/10.1093/rof/rfy008

6. Bhagat, S., \& Bolton, B. (2008). Corporate governance and firm performance. Journal of Corporate Finance, 14(3), 257-273. https://doi.org/10.1016/j.jcorpfin.2008.03.006

7. Boursier, G. (2010, November 28). L'intesa [Television program]. Retrieved from https://www.report.rai.it/dl/ docs/1494884587013agg_intesa_report.pdf

8. Boursier, G. (2010, November 28). L'intesa aggiornamento del 12/10/2008 [Television program]. Retrieved from https://www.report.rai.it/dl/docs/1494884587013agg_intesa_report.pdf

9. Bracalini, P. (2008). Dal logo alle bibite: così sono lievitati gli sprechi. Il Giornale. Retrieved from http://www.ilgiornale.it/news/logo-alle-bibite-cos-sono-lievitati-sprechi.html

10. Brigatti, G. (2017, October 11). Ryanair e EasyJet, conviene ancora volare low cost? La Repubblica. Retrieved from https://www.repubblica.it/economia/2017/10/11/news/ryanair_o_easyjet_conviene_ancora_volare_con_le_low_co st_-177775446/

11. Brogi, M. (2016). Corporate governance. Milan, Italy: Egea.

12. De Santis, G. (2015). Crac Alitalia, condannati gli ex vertici otto anni e otto mesi a Cimoli. La Stampa. Retrieved from https://www.lastampa.it/economia/2015/09/28/news/crac-alitalia-condannati-gli-ex-vertici-1.35228107

13. Dittmar, A., \& Marth-Smith, J. (2007). Corporate governance and the value of cash holdings. Journal of Financial Economics, 83(3), 599-634. https://doi.org/10.1016/j.jfineco.2005.12.006

14. Ferramosca, S. (2018). Politiche di bilancio e corporate governance - relazioni ed effetti economico - aziendali. Giappichelli

15. Freeman, R. (1984). Strategic management: A stakeholder approach. Boston: Pitman.

16. Freeman, R. (2001). A stakeholder approach to strategic management (Darden Business School Working Paper No. 01-02). https://doi.org/10.2139/ssrn.263511

17. Gabanelli, M. (2010, November 28). L'intesa aggiornamento del 12/10/2008 [Television program]. Retrieved from https://www.report.rai.it/dl/docs/1494884587013agg_intesa_report.pdf

18. Gabanelli, M. (2012, December 2). Come è andata a finire [Television programme]. Retrieved from https://www.raiplay.it/video/2012/12/Report-del-09122012-cbf69c4f-e41e-4dd8-a2b7-42cbcc0afbd4.html

19. Jensen, M. (2001). Value maximization, stakeholder theory, and the corporate objective function. Journal of Applied Corporate Finance, 14(3), 8-21. https://doi.org/10.1111/j.1745-6622.2001.tb00434.x

20. La Rocca, M. (2016). Valore economico dell'impresa, questo sconosciuto. Componenti, dimensioni e vincoli connessi al più importante concetto aziendale, alla base del successo dell'impresa. Social Science Research Network. Retrieved from https://papers.ssrn.com/sol3/papers.cfm?abstract_id=2788468

21. La Rocca, T. (2016). Il valore delle risorse finanziarie. Milano, Italia: Franco Angeli.

22. Massaro, F., (2017). Alitalia, tre commissari: Gubitosi, Laghi e Paleari. Arriva il prestito ponte: 600 milioni, interessi al 10\%. Corriere della Sera. Retrieved from https://www.corriere.it/economia/17_maggio_02/alitaliaok-cda-commissariamento-no-modifica-voli-588c5ae2-2f20-11e7-88d3-be5206e98599.shtml

23. Myers, S. (1977). Determinants of corporate borrowing. Journal of Financial Economics, 5(2), 147-175. https://doi.org/10.1016/0304-405X(77)90015-0

24. Pavlovic, D., \& Babic, D. (2018). Recent trends in assessment of proposed consolidations in EU airline industry From discretion to arbitrariness. Transport Policy, 69, 65-77. https://doi.org/10.1016/j.tranpol.2018.06.003

25. Rappaport, A. (2012). Salvare il capitalismo. Come riprendere il controllo della finanza e tornare a creare valore a lungo termine. Franco Angeli.

26. Scalfari, E. (2008). Il pifferaio, gli allocchi e l'asso di Colaninno. La Repubblica. Retrieved from https://www.repubblica.it/2008/09/sezioni/economia/alitalia-27/scalfari-colaninno/scalfari-colaninno.html

27. Singer, P., \& Sirianni, C. (2015). La Corporate governance - Elementi di teoria e profili operative. Giappichelli

28. Solleviamoci. (2009, October 10). Alitalia falliva, i manager s'arricchivano'I piccoli risparmiatori: ecco le cifre. Retrieved from https://solleviamoci.wordpress.com/2009/10/11/\%C2\%ABalitalia-falliva-i-managersarricchivano\%C2\%BB-i-piccoli-risparmiatori-ecco-le-cifre/

29. Tombari, U. (2018). Informazione societaria e corporate governance nella società quotata. Giappichelli

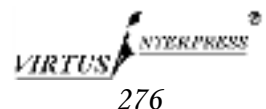




\section{APPENDIX A}

\section{Managerial profiles in Alitalia}

Fausto Cerreti (1996-2003): is a competent manager, graduated in aeronautical engineering. During his professional career, he worked for companies operating in the aeronautical sector. He also was President of Assaereo, the trade association (affiliated to Confindustria) matching airline companies in Italy. In an interview, he identifies the beginning of Alitalia's decline when people related to political parties headed the company.

Giuseppe Bonomi (2003-2004): is an Italian politician graduated in law. He was Commissioner in the cities Varese and Milan before being a deputy for the party "Lega Nord". Moreover, he was initially a member and then chairman of the Board of SEA, the company that manages Linate and Malpensa airports in Milan. During the year 2003, he became chairman of Alitalia. His appointment was political, because of his close relationship with political parties. It was clear that he wanted both Linate and Malpensa with a high level of air traffic.

Giancarlo Cimoli (2004-2007): graduated in chemical engineering. He had large experience as manager of an important chemical company. Berlusconi's Government appointed him as President of Alitalia. He did the "Industrial Plan 2005-2008". His aim was to balance accounts from 2006 and get profits since 2008. However, once fallen the Board of Directors, the Finance Minister Tommaso Padoa-Schioppa decided to dismiss him, because he did not achieve any of his goals. Cimoli left Alitalia with a large bonus, despite the company reported heavy losses.

Berardino Libonati (2007-2007): is an experienced lawyer on commercial and bankruptcy law. On February 9, 2007, The Finance Minister Tommaso Padoa-Schioppa suggested to him as President of Alitalia, replacing Giancarlo Cimoli. The company's management was composed of a Board of Directors, chaired by Libonati and with Gabriele Spazzadeschi and Giancarlo Schisano as members. After he negatively attempted privatization, he resigns. However, he promised great things, but 17.000 employees were layoff and the company lost nearly one million euro per day. Nevertheless, his salary was 2.791.000 euro.

Maurizio Prato (2007-2008): got a degree in law and economics. Since 1978, he had important managerial positions for several companies belonging to the Groups IRI and Fintecna. They appointed him as President of Alitalia and, simultaneously, he left his role for Fintecna. On April 2, 2008, during negotiations with Air France, Maurizio Prato leaves Alitalia to return Fintecna. Codacons reports that while the company was collapsing, Prato gained 2.170 euro per day, corresponding to 326.000 euro in five months. Aristide Police succeeded him three days before the election.

Aristide Police (2008-2008): graduated in law. He is an expert in administrative law. His career began in the academic world. Before his arrival to Alitalia, he collaborated with the Ministry of Economic Development to write the decree on administrative simplification for business life. His appointment as President of the board was a surprise. He joined Alitalia on April 3, 2008, and remained for a few months until the Commissioner's arrival.

\section{CEOs}

Francesco Mengozzi (2001-2004): is a manager with a large experience in public companies. He also had previous experiences in Fintecna, Rai and the National Railways before moving to Alitalia. The Amato Government in 2001 choose him as the right man for Alitalia, but his three years mandate had no brilliant result. According to a report from the Guardia di Finanza (financial police), Mengozzi, during his three years in Alitalia, received wages for 3.7 million euro.

Marco Zanichelli (2004-2004): is a business executive whose career has developed in Alitalia up to the role of CEO on February 24, 2004. He resigned on May 7, 2004, together with President Giuseppe Bonomi. Giancarlo Cimoli took his place.

Giancarlo Cimoli (2004-2007): held the role of President and CEO for the airline at the same time. His career is above highlighted in the section dedicated to Presidents of Alitalia.

Cramer Ball (2016 -2017) started his career as an accountant. He was a manager of the treasury for Transfield Holdings. He was a member of the Australian Society of Accountants. He also was Director of the Asia Pacific and Oceania for Etihad Airways before moving to Air Seychelles. His attention to customer satisfaction led to brilliant results for Air Seychelles. Cramer Ball was Alitalia's Chief Executive Officer from March 2016 to April 2017.

\section{Special Commissioner}

Augusto Fantozzi (2008-2011): graduated in law. He was several times minister for Dini and Prodi Governments. He ran for left-centre political parties in parliamentary elections. On August 29, 2008, Berlusconi's Government designated him as a special Commissioner of Alitalia. He resigns on July 19, 2011, thinking the Government did not trust him anymore.

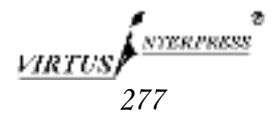

